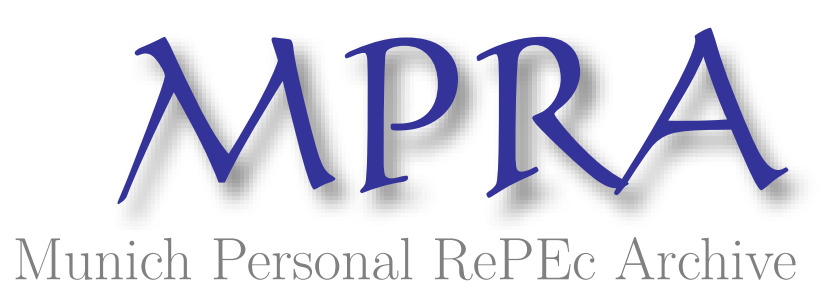

\title{
A fire department for the Euro area: reflections on a fiscal risk-sharing capacity
}

Gabrisch, Hubert

Wiesbaden Institute for Law and Economics

18 January 2018

Online at https://mpra.ub.uni-muenchen.de/83965/

MPRA Paper No. 83965, posted 19 Jan 2018 02:37 UTC 


\title{
A fire department for the Euro area: reflections on a fiscal risk-sharing capacity ${ }^{1}$
}

\begin{abstract}
This essay investigates the necessity of and options for a central fiscal risk-sharing capacity in the Euro area. How can these aims be reconciled with the member countries' responsibility for sound fiscal policy that also considers constitutional sovereignty, institutional efficiency and economic effectiveness? As a result, such a capacity can be created as an overlay over the existing fiscal framework without treaty changes and can complement it according to the distinct features of the monetary union. A stabilization fund dedicated to investment appears to be the best solution in light of the applied criteria.
\end{abstract}

JEL codes: E62, F45,H77

Keywords: risk-sharing, EU budget, monetary union

\section{Introduction: The challenge}

The series of banking and sovereign debt crises after 2008 challenge the existing architecture of the European Union (EU) and its global political standing. Political inertia and popular anti-EU sentiments in many member states resemble the 'Euro-pessimism' of the 1970s and 1980s, which was resolved with the Single European Act of 1987. Its substantial reforms paved the way for the present architecture of the EU, which is now in peril. The feeling that 'something must be done' is widespread among politicians, the press and the academic world.

This essay offers reflections on one substantial reform proposal, namely, the introduction of a 'central fiscal capacity' to the euro area (EA), whereby its risk-sharing function is set in contrast to the disciplinary function of the existing fiscal architecture imposed by the Maastricht treaties ('the Treaties' hereafter) ${ }^{2}$. One might imagine the analogy of a fire department of a larger town whose task is not only to extinguish a burning building but also to prevent the fire from spreading outward to the neighbourhood. In earlier times, each house owner was responsible for his/her own house. However, given the greater housing density, modern cities have a fire department available. The EA regime contains

\footnotetext{
${ }^{1}$ I express my thanks to the participants for their questions and critical comments at the 2017 CEEI conference in Vienna on November 20, 2017, organized by the Austrian National Bank, which I try to address in this revised version. The final version will be published in the forthcoming CEEI 2017 conference volume.

${ }^{2}$ Treaty on European Union and Treaty on the Functioning of the European Union.
} 
no EA-wide provision to address the common shocks and spill-over effects of national reforms and fiscal adjustment programmes. Everything is left to individual countries or to private capital and credit markets. The introduction of a central fiscal capacity would be a transformation of the EA's present architecture, similar to the transformation of privately organized and competing fire departments into publicly organized departments in the $18^{\text {th }}$ century. However, when one advocates a substantial transformation of the EU/EA institutional framework, one has to respect the unique constitutional character of the EU, which is not a single state or a federation like the U.S. or Canada and will not become one, at least in the foreseeable future. The $\mathrm{EU}$ is a confederation of states at best. The introduction of a central fiscal risk-sharing capacity is closely related to the sensitive issue of member countries' sovereignty. The distribution of sovereign rights is precisely fixed in the Treaties. It is difficult to establish a sovereign central risk-sharing entity without affecting the existing distribution of sovereignties through treaty changes. Therefore, to extend the existing literature, this essay will also discuss the issue with respect to the problem of constitutional sovereignty

The rest of this essay is divided into four parts: It takes as its starting point the view that risk sharing in the EA has many shortcomings, as discussed in Section 2. Section 3 provides empirical arguments as to why the existing fiscal framework is neither institutionally efficient nor economically effective to protect the EA economy against shocks and their proliferation. Section 4 presents a discussion about the design of an EAspecific fiscal risk-sharing capacity using the three criteria of sovereignty, institutional efficiency, and economic effectiveness. In my view, a stabilization fund dedicated to investment solves the sovereignty problem and meets the efficiency and effectiveness criteria best. The final section summarizes and concludes.

\section{The shortcomings of the risk-sharing regime of the EA}

In a monetary union, full cross-border income risk sharing is given when consumption growth rates are equalized across all countries. The standard approach to testing and estimating the size and channels of risk-sharing across countries is the methodology proposed by Asdrubali et al., 1996. This methodology identifies three channels:

- Capital markets: internationally diversified portfolios smooth income shocks in the issuer economy for the holder economy; more integrated capital markets reinforce 
private risk-sharing.

- Credit markets: international banks could continue to supply credit to a country with an idiosyncratic output shock when they dispose of savings from another country.

- Government channel: fiscal transfers or grants through integrated fiscal systems would protect private consumption (e.g., via an unemployment insurance scheme) or government consumption from output shocks.

Figure 1 compares risk-sharing in the EU to existing single-state federations of a similar economic level until 2010 (Allard et al. 2013 in an IMF study). This picture illustrates what makes the EU and EA distinct compared to 'true insurance unions' (Vandenbroucke 2017: 154):

Figure 1: Risk Sharing in Different Federations (different periods before 2010)

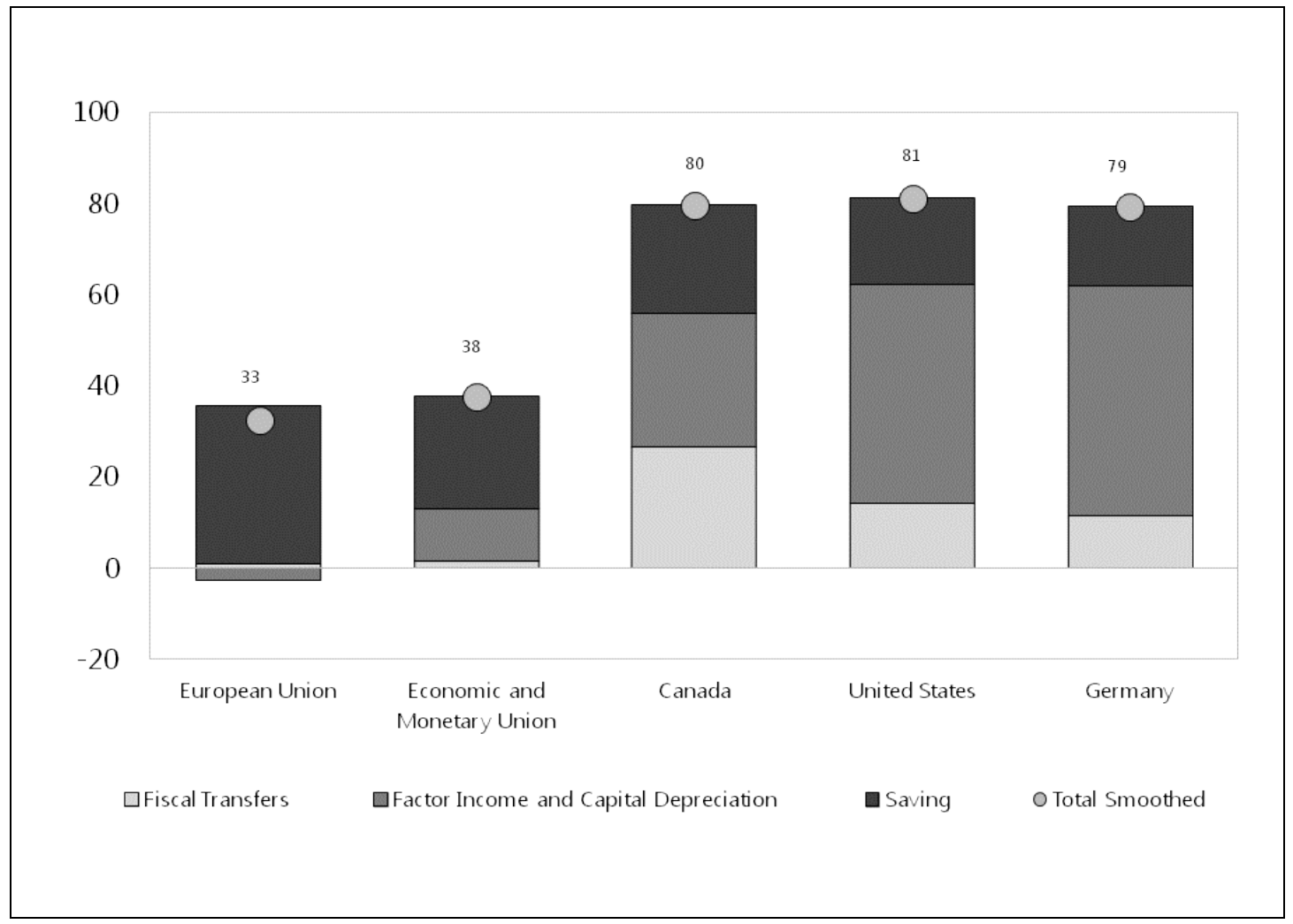

Note: Fiscal transfers = government channel; factor income and Capital Depreciation = capital market channel; Saving = credit market channel.

Source: Allard et al. 2013, with further references.

- Less overall insurance. While federations such as the U.S., Canada or Germany 
managed to smooth approximately 80 percent of local income shocks on private consumption, the euro area only managed to insulate half of that amount - in other words, when the GDP contracted by 1 percent in one of the euro area countries, households' consumption in that country was depressed by as much as 0.6 percent (as opposed to 0.2 percent in the U.S., Canada or Germany).

- Less market-based insurance. Capital markets in the euro area played much less of an insurance role compared to other areas, in part because cross-border ownership of assets within the euro area remained more limited than, for example, across U.S. states or German Länder despite the single market.

- Little fiscal risk sharing. Cross-country fiscal risk sharing was almost non-existent, both in the EU and the euro area compared to the cross-state transfer and grant schemes in the U.S. or Canada or the Financial Equalization Scheme between the Federal Government and the Länder in Germany.

Other empirical studies that extend beyond 2010 confirm the situation (Poncela et al. 2016, Ferrari and Picco 2016, Furceri and Zdzienicka 2013). Many proponents of a central fiscal capacity ${ }^{3}$ argue that the lack of an appropriate fiscal risk-sharing instrument at the EA level may have contributed to aggravating the severity of the economic downturn in the euro periphery and delayed recovery throughout the area. For example, Furceri and Zdzienicka (2013:9) find that the credit market channel tends to break down in periods of severe downturns and financial crisis when risk sharing is most needed because international credit markets become unwilling to grant loans. The authors conclude (Furceri and Zdzienicka 2013:15) that a supranational risk-sharing mechanism would be able to provide full insurance against very severe, persistent and unanticipated downturns. Cimadomo et al., 2017 obtain somewhat different results. The authors find a slight rise in consumption smoothing in the aftermath of the euro crisis due to credits from the European Financial Stability Facility (EFSF) and the European Stabilization Mechanism (ESM) to Greece and other euro economies after 2010. Notice here that the conditionality of these credits might have contributed to drastic interruptions in consumption, e.g., in Greece, while their size may have only partly offset these negative effects.

\footnotetext{
${ }^{3}$ For a collection of such articles, see Intereconomics, vol. 52 (3), 2017.
} 
Eight years after the outbreak of the Greek crisis, there seems to be a consensus among many economists (Wyplosz 2013, Baldwin et al. 2015 ) that the mismanagement of this crisis contributed to its proliferation to other countries and that one reason for this mismanagement is the politically binding constraints of the fiscal rules of the Treaties. At least, one may expect that an EA fiscal risk-sharing capacity would have protected countries with a relatively sound fiscal policy stance, such as Spain and Ireland, against contagion from the Greek crisis. Despite these insights of the literature, the response of the official EU - the Four and Five Presidents' reports (EU Commission (2012 and 2015a) and the recent EU Commission's 'Reflection Paper' (EU Commission 2017a)—remains vague with respect to a fiscal risk-sharing instrument. Apparently, the official EU favours stronger private risk-sharing mechanisms in the EA as documented by the banking union and the recent proposal of a capital market union (EU Commission 2015b). Some authors argue that the implementation of a capital market union would ensure complete crossborder risk-sharing (Brühl et al. 2015, Demary et al. 2015, Véron and Wolff 2016). Other authors advocate the 'restoration' of decentralized responsibilities of government debt and financial sector reforms (Fuest and Peichl 2012, Feld and Osterloh 2013).

The theoretical basis of the superiority of private risk-sharing is modelled in the seminal paper by Allen and Gale, 2000, who have formally shown that with increasing connectivity in a credit network (= risk-sharing), individual and systemic risks will shrink. Unfortunately, experience has proven that the idea does not work in all circumstances. After 40 years of financial market liberalization and increasing cross-border trade with securities, it is difficult to recognize that systemic financial fragility is fading; the best example is the financial crisis of 2007/2008 in the U.S., possibly the world's most integrated financial market. A second generation of financial network models attempts to explain why the first-generation idea of increasing risk-sharing might fail. In contrast to Allen and Gale (200), Battiston et al. (2012) emphasize against the dynamic effects of financial stress induced by the work of the financial accelerator: The propagation of an idiosyncratic shock today makes each network member more vulnerable to a further liquidity shock tomorrow, even when the initial shock has been absorbed. The presence of dynamic effects may lead to a systemic crisis because of more individual risk-sharing.

\footnotetext{
${ }^{4}$ According to its authors, this internet publication presents a consensus narrative of the causes of the EZ Crisis.
} 
Acemoglu et al. (2013) show how the fragility of a network depends on the architecture of the network. Networks are able to absorb minor daily shocks to one of their nodes. However, a complete network might fail in the event of severe shocks (such as the U.S. real estate shock) in the absence of excess liquidity of at least one node or external creditors. These second-generation models reveal the shortcomings of private risk-sharing channels. However, this does not mean that a change of the existing EA disciplinary fiscal architecture is absolutely necessary. Therefore, the next section will discuss the shortcomings of this regime.

\section{Why fiscal discipline is not a substitute for fiscal risk-sharing}

Most single states and large federations have public risk-sharing instruments at their disposal. This is the result of a historically long process of power centralization combined with intra-state fiscal federalism. Economics justifies a fiscal federal system with the argument that in the absence of exchange-rate prerogatives and with highly open economies, 'local governments simply have very limited means for traditional macroeconomic control' (Oates 1999). ${ }^{5}$ Traditional control' means the use of anti-cyclical monetary and fiscal policies, mostly in a way that is combined and coordinated between the central bank and the treasury.

The EA is based from the outset on the principle that shock absorption requires structural reforms and fiscal adjustments at the country level. The fiscal framework that was adapted to the monetary union is established in the EU Treaties of 1997 (the principle of no-bailout and the ban on central bank financing), the Stability and Growth Pact (SGP) and its later reforms, the Two-Packs for increased surveillance in 2011, and the Fiscal Compact of 2012. Its substance is fiscal discipline, not risk-sharing. The underlying idea is the prevalence of idiosyncratic shocks caused by unsound policy discretion and noncompetitive economic structures. Therefore, the undertaken reforms underline the relevance of eliminating structural budget deficits as the result of policy discretion. Another belief is that many shocks have a cyclical component, and the EU fiscal framework provides all the rules for national fiscal policies to address them. Sound fiscal policies use the automatic stabilization function of revenues and expenditures to ensure a balanced budget throughout the cycle. Finally, the centralized monetary policy disposes of all instruments to address common macroeconomic shocks and a common business cycle.

\footnotetext{
${ }^{5}$ Oates published his essay on fiscal federalism in the year of the euro introduction, and many passages in this essay read as if they address this event.
} 
However, the past 20 years, particularly the turbulent period since 2009, have revealed some striking and plainly visible shortcomings of this approach. First, an more trade and financial integration transforms an idiosyncratic shock into a common shock via the trade and financial multipliers, as in my analogy of a fire spreading out to its neighbours. Figure 2 underlines why idiosyncratic shocks, justifying a country-specific reform approach, lost their importance. The figure shows the Hodrick-Prescott trend-adjusted real GDP rates of change for each of the twelve original EA countries and their correlation with the EA business cycle on a quarterly basis for three consecutive periods since 1995. A coefficient of one depicts complete synchronization with the EA business cycle. As a result, synchronization has increased continuously since 1995. In the last period, a one percentage point deviation from the trend rate of GDP in the euro area is correlated with a 0.65 percentage point deviation on average in each country. For example, a euro areawide shock is almost completely transferred to France and Germany and vice versa.

Figure 2: Business cycle synchronization in the EA (coefficients of correlation with the EA) $)^{\mathrm{a}}$

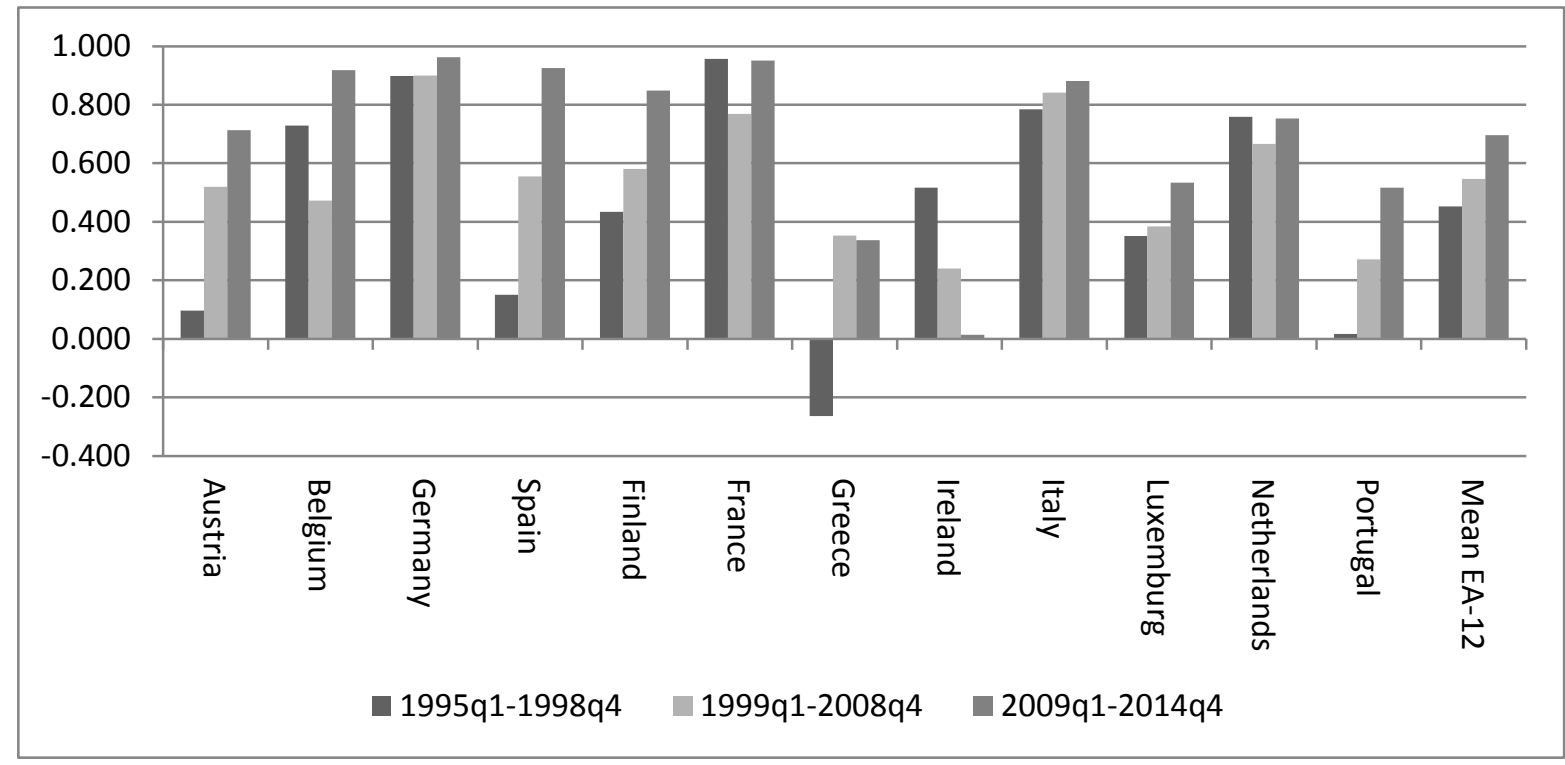

${ }^{\text {a }}$ HP trend adjusted real GDP growth rates.

Sources: Own calculations and illustration based on Eurostat quarterly GDP data.

Accordingly, harsh fiscal consolidation in one country would trigger negative spillover effects to other countries. In an IMF study, Poghosyan, 2017:26, it is estimated that a fiscal consolidation of 1 percent of the GDP in Germany would reduce the GDP in ten EA countries by 0.3 percent after five years. Hence, the more the cross-country cycles are 
correlated, the higher the need is for a common fiscal instrument, which protects country A against losses caused by unilateral fiscal adjustments in country $\mathrm{B}^{6}$

Figure 3: Standard deviation (SD) of GDP rates of change (cyclical component and periodical trends ${ }^{\mathrm{a}}$

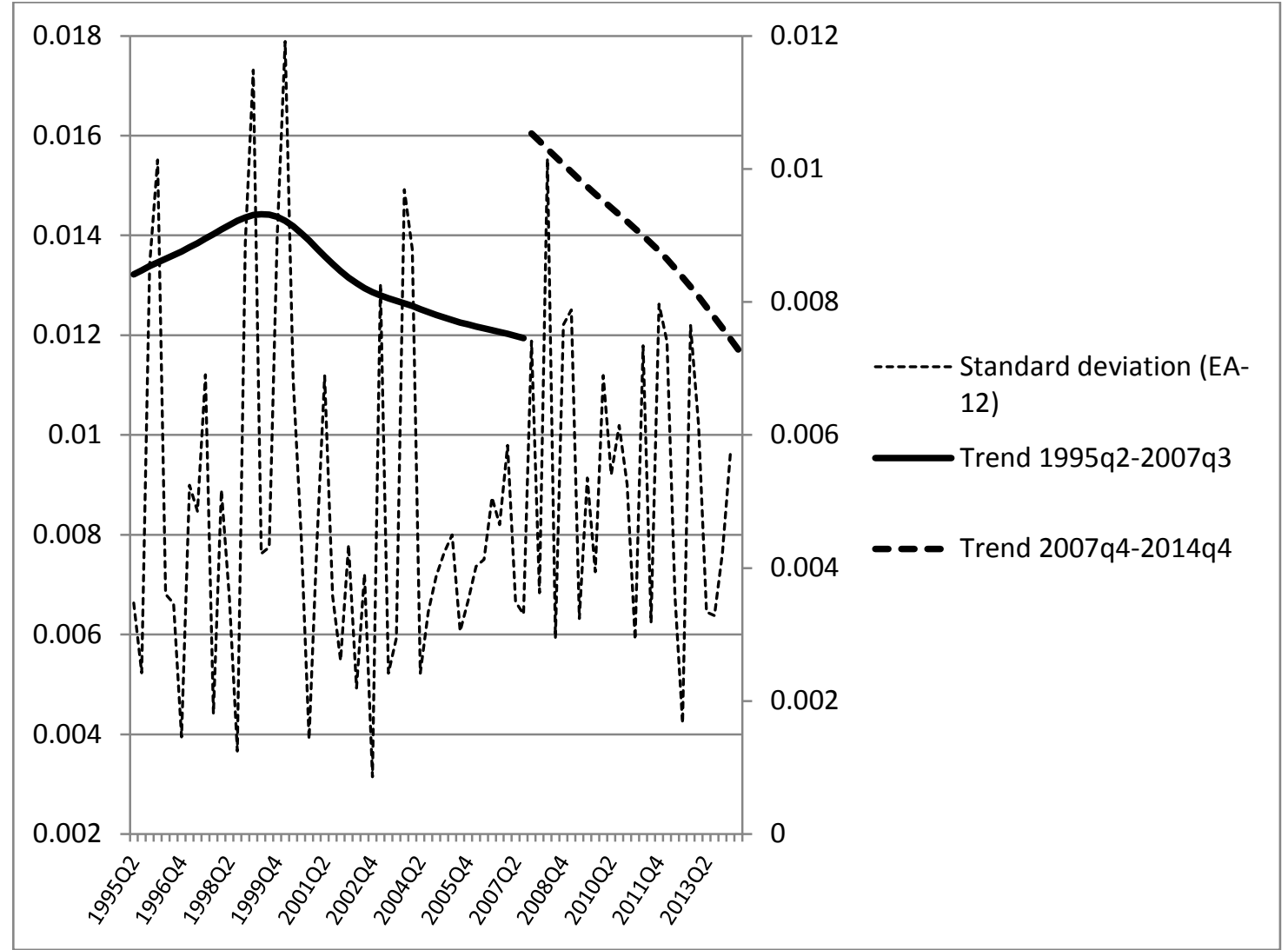

${ }^{\mathrm{a}} \mathrm{HP}$ trend adjusted data for the original EA-12.

Sources: Own calculations based on Eurostat quarterly GDP data.

Another matter of concern is the rising divergence of business cycle amplitudes (a measure for the degree of consumption smoothing) in times of strong economic turbulence. Figure 3 depicts the standard deviation (SD) of the cyclical component of the GDP rate of change for the EA-12 countries for each quarter between 1995q2 and 2014q4, complemented by the trend lines for the calm period of 1995q1-2007q3 and the period 2007q4-2014q4 that includes the financial and debt crisis episodes, including the fiscal adjustment programmes. The first solid line shows a declining divergence of amplitudes after the introduction of the euro until the end of 2007. The second, dotted trend line

\footnotetext{
${ }^{6}$ In an OECD study (OECD 2014: 69ff), the authors argue that a central fiscal capacity is not needed because of the high business cycle synchronization in the EA. However, the reality is the reverse: Synchronization amplifies spillover effects and justifies a fiscal risk-sharing instrument.
} 
reveals a jump in the SD to substantially higher levels in the following quarters and a return to the calm period level in 2013. Apparently, less cross-border consumption smoothing in turbulent times is the combined effect of country-specific fiscal adjustment programmes and strong feedback from spillover effects on other EA countries.

A third matter of concern is that the monetary policy of the ECB does not dispose of all instruments to deal with common shocks. Centralized monetary and decentralized fiscal policies are not complete substitutes, particularly when the conventional monetary policy approaches the zero lower bound. Demand is suppressed, and the private sector is not able to absorb all workers released in non-competitive industries. Figure 3 above illustrates that the divergence in cycle amplitudes returned to its pre-crisis level only after the ECB emphasized its power in the summer of 2012 when it announced the Outright Market Transactions (OMT) programme. The 'unconventional' monetary policy stopped the acute phase of the crisis (Wyplosz 2017) but with 'diminishing returns' (Carnot 2017, Begg 2017): quantitative easing contributed to an increase of financial asset prices, thus increasing the financial fragility of the whole financial system.

Finally, the cyclical component of the fiscal budget should breathe via the automatic stabilization function of revenues and expenditures. The operation of automatic stabilizers is meaningful only when the cyclically adjusted budget is sufficiently sensitive to income shocks. When governments were recently forced to reduce their structural deficits through social and tax system reforms, this had the displeasing effect of also reducing the sensitivity of the cyclical budget. In Figure 4, a positive value means the stabilizers act in a normal direction: a decline in GDP leads to a higher deficit and vice versa. The grey bars illustrate the large differences in the cyclical sensitivity among the countries in the entire period of 2008-2016 due to country traditions and recent reforms of the social and tax systems. This corresponds to substantially different income multipliers of automatic adjustments. The dark bars shed light on the years of reinforced fiscal consolidation, which are 2013-2014. There are many cases of an automatic de-stabilization: a negative GDP rate of change is related to a positive change (improvement) in the cyclical component. The picture reveals an almost negligible average sensitivity in both the EU and the EA. 
Figure 4: Income sensitivity ${ }^{\mathrm{a}}$ of the cyclical component of national budgets (28 EU countries $(2010-2016)^{b}$

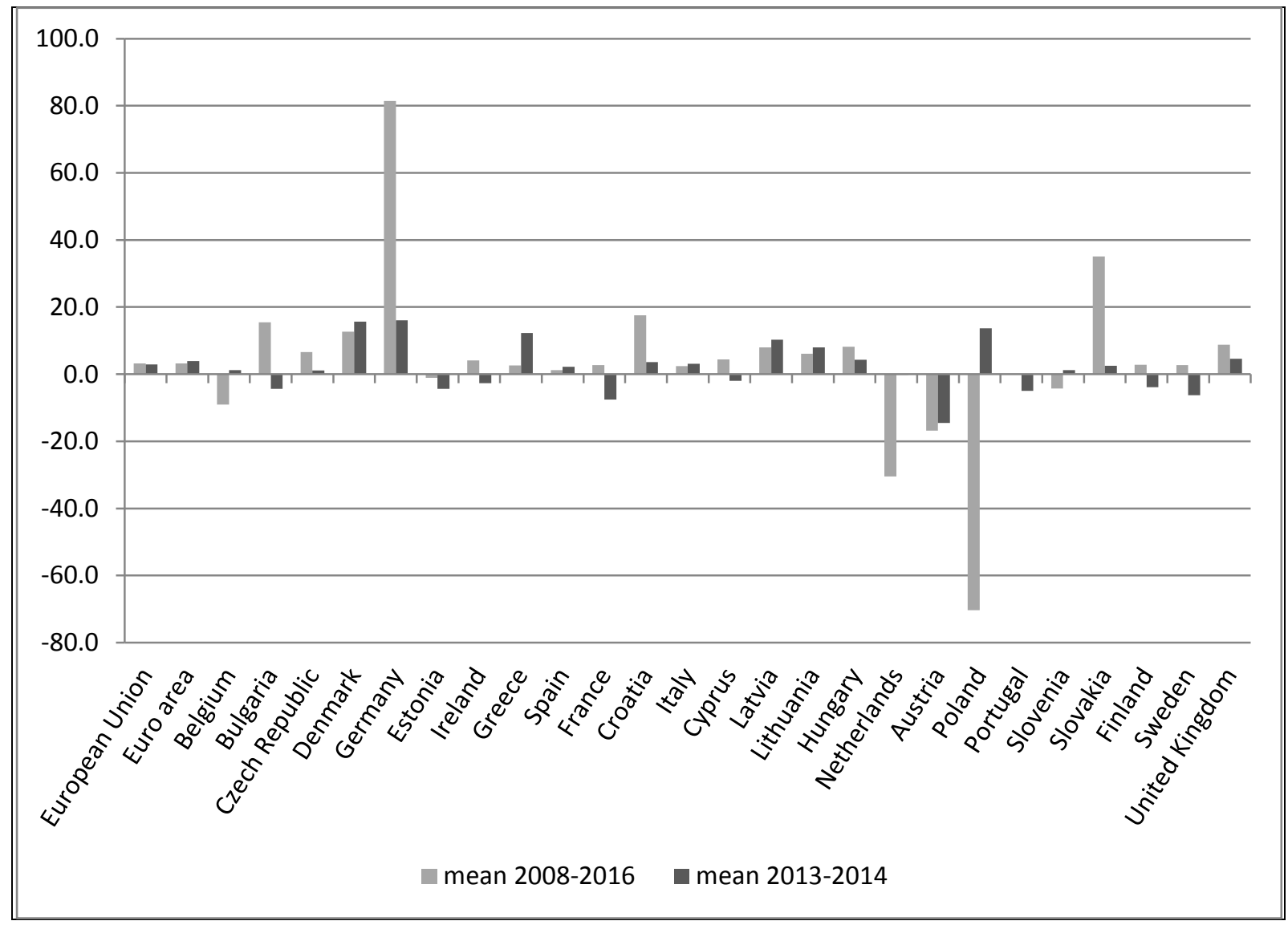

${ }^{a}$ Calculated as the ratio between the percentage change of the cyclical component and a one percent rate of change of the nominal GDP in the period $2008-2016$. - ${ }^{\mathrm{b}}$ Cyclical adjustment according to the potential output concept.

Sources: Author's presentation based on Ameco (GDP) and Eurostat (cyclically adjusted general government net lending) data.

One should not be surprised that EA countries would want to protect themselves against negative spill-over effects of reform and consolidation actions in other countries. However, unilateral responses lead to institutional disintegration instead of convergence. It seems that it would be more efficient to have a common risk-sharing instrument at its disposal. This could protect member countries with sound fiscal parameters from the spillover effects of harsh fiscal consolidations in other countries and could also grant assistance to the non-fiscal sector of a country, in which the fiscal sector is forced to consolidate according to the existing rules. 


\section{Criteria for and main features of an EA-specific fiscal risk-sharing capacity}

As a substantial transformation of the existing EA architecture, the idea of a central fiscal capacity reaches far beyond purely economic considerations; it touches on the member countries' self-conception of being sovereign states. This is one reason why various EU reports and reflection papers underline the need for such a reform but never crossed the Rubicon of precise concepts despite the already considerable collection of proposals in the area (for an overview, see Iara 2017). Therefore, the criteria for the design of a central fiscal capacity reach beyond purely economic criteria, such as efficiency and effectiveness. They also include the problem of constitutional sovereignty.

Sovereignty: A central fiscal capacity equipped with efficient and effective risk-sharing instruments should be sovereign in the sense that it is not subject to orders from its constituents or addressees of its operations - the national governments. Based on this definition, sovereignty denotes independence, and independence is a prerequisite for policy discretion. Goodhart and Lastra (2017) discuss this issue for the case of central bank independence: indeed, the ECB is an example of a sovereign, independent central bank. However, there is an additional property of ECB sovereignty: member countries have not only delegated important parts of their monetary policy sovereignty to the central bank but did so by adopting the EU Treaties. These Treaties have no provision that a member country can unilaterally leave the monetary union. When EA reforms include the creation of a fiscal entity sovereign in this strict sense, a change of the Treaties would be necessary. However, the architecture of the EU also considers entities to be sovereign without a former change of the Treaties, i.e., the ESFS and the ESM. They are independent and have discretionary policies. As less strictly sovereign entities, they were established by secondary laws (Council directives and regulations) without the transfer of national sovereign rights to a central level. The proposal of an EMF is precisely based on the less strict prerequisites of sovereignty. Hence, a central fiscal capacity can be designed in a similar way, and it would be an overlay over the existing system, completing it according to the distinct features of the EA. Member states remain fiscally sovereign and responsible for their national fiscal policy stance, but the central entity is responsible for a European perspective in fiscal policies.

Efficiency: According to the Tinbergen rule (Tinbergen 1952), each achievable policy goal needs at least one linearly independent instrument. When one instrument incorporates two not completely substitutable functions, a trade-off may emerge between them. This 
argument justifies the historic separation of government entities for fiscal policies (the treasury or finance ministry) and the monetary policy (the central bank). Likewise, a trade-off might appear when the risk-sharing and the fiscal discipline goals are part of one instrument. If so, the risk-sharing function would have to compensate for the negative effects stemming from the disciplinary arm of the instrument, clearly reducing the efficiency of the measures undertaken. I mentioned the Greek example in Section 2. Two separate fiscal policy instruments, one at the national level and one at the central level, would both result in greater efficiency. The principle of 'sound fiscal policy' at the national level can be reconciled with the principle of functional finance at the central level. The disciplinary arms of the existing fiscal framework, including the principle of no bail-out, would become more reliable, while the stabilizing arm at the central level would mitigate the spill-over effects of harsh country-level consolidation programmes.

Effectiveness: A central risk-sharing instrument should achieve its overarching goal of consumption smoothing by softening the cross-country spill-overs of shocks of various origins and returning some control to the EA economy. Here, the relationship between discretion and automatic stabilization is essential. A risk-sharing capacity may address cyclical shocks and soften the cross-border spill-overs, induced by the different national systems of automatic stabilization. However, a substantial problem is how to identify the difference between a cyclical and a severe non-cyclical shock. When the shock is persistent with long-term unemployment, the system might change from risk-sharing to redistribution by transfer (Allard et al. 2013), which is generally considered undesirable among European politicians and the population. Discretion is a more appropriate policy concept that also reduces the moral hazard that is inherent in any support operation (Goodhart and Lastra 2017: 13). Furthermore, a new legal entity is not sui generis subject to the rules and quantitative adjustments of the SGP and the Fiscal Compact, which apply only to national governments, which allows for the design of rules for borrowing for financing risk-sharing measures. Bonds of the central fiscal capacity, financed by its own resources, would stabilize private risk-sharing by providing a common safe asset to the financial markets.

I will briefly evaluate four proposals for a central risk-sharing capacity in the EU applying these criteria: $(i)$ a full-fledged EA budget, (ii) a European unemployment benefits system (EUBS), (iii) a stabilization fund, and (iv) a European Monetary Fund (EMF). 
A full-fledged EA budget with an appropriate authority ('European government' or 'treasury') likely has the greatest possible implications for the sovereign rights of member counties. In contrast to the other proposals, its realization would probably require a change of the Treaties because a full-fledged budget would fulfil stabilization ('risk-sharing') as well as allocative and distributive functions (inclusion of regional and structural funds). Thus far, the sensitive issue of member sovereignty is a primary hurdle for the realization of this concept. It is difficult to imagine that a full-fledged budget can be implemented through Council directives and regulations. Since the budget would not sui generis be subject to the existing fiscal framework with its disciplinary functions, its efficiency in tracking its goals should not be affected. The budget would include permanent tax revenues and expenditures that are partly uncoupled from the occurrence of shock events. The revenue side would automatically respond when a country is hit by a shock; this country would contribute less. However, the effectiveness of revenue-side automatic stabilizers would be very limited (see also Figure 4 above). Assuming a balanced budget of approximately 2 percent of the EA GDP, a 5 percent decline in revenues would support the economy with 0.1 percent of its GDP, which is non-negligible but unimpressive given the implicit magnitude of a large shock (Carnot 2017: 1519). Therefore, a central budget should instead be built on discretionary expenditure policy. Through discretionary interventions, the fiscal entity would become a fiscal partner and counterpart to the ECB at a level-playing field - a prerequisite to return some control over the EA economy in cooperation with the ECB that would become less prone to exceed its power. This quality applies to all proposals discussed here.

A EUBS: The classical risk-sharing mechanism in each welfare state is the unemployment insurance system, which responds automatically to the national business cycle and, in doing so, 'helps it neighbours' (Vandenbroucke 2017). The case for a centralized system is a symmetric shock to all members of a monetary union. When all members have extremely different national unemployment benefit systems, risk-sharing in countries with less developed systems would be weaker, and negative spill overs would change from a symmetric to an asymmetric shock. The EUBS would compensate for this effect. Because the system would work in combination with the national systems, the size of the common funding, an addition to national social security contributions, would be lower in terms of the common GDP compared to the national systems. ${ }^{7}$ Thus, no member country's

\footnotetext{
${ }^{7}$ Dullien (2008) calculated the volume of a basic version at 0.65 per cent of the euro area GDP.
} 
sovereignty status would be changed. The system can be established within a European secondary law through a Council regulation or directive. A more substantial problem is severe non-cyclical shocks. In the case of persistent shocks with long-term unemployment, the system would change from risk-sharing to redistribution. Redistribution can become a perverse form of a beggar-thy-neighbour policy. The most striking example mentioned in the literature is Germany with its high unemployment and subsequent wage moderation policy in the two decades since state unification in 1990. If a European unemployment insurance system had existed at that time, it might have haphazardly directed transfers from the strongly growing Spain to a stagnating Germany.

A stabilization fund: A simpler and more effectual concept is a stabilization fund (Carnot 2017) when dedicated to compensating for discretionary cuts of the national budgets' investment expenditure, which is the first victim when governments are asked to consolidate according to the rules of the existing fiscal framework. Activated only in cases of large country-specific and common shocks, it is most similar to my analogy of a fire department, while sovereign national governments remain responsible for sound fiscal policies, similar to homeowners remaining responsible for appropriate protection against the outbreak of a fire. The fund would support infrastructural and private investment overwhelmingly — not through transfers but grants that create an equivalent through future income in the receiving countries. As a sovereign entity, the fund makes discretionary decisions within its rules after a case-by-case determination in terms of whether a government or any other agent is eligible for assistance. The initial capital stock of the fund would be provided by a contribution of member states. The capital stock may serve as collateral for the initial issuance of bonds, which establishes a market for low-risk securities and may be acceptable for ECB financing.

A European Monetary Fund (EMF): Like a stabilization fund, an EMF may be established by directives and regulations. According to many proponents and the recent proposal of the EU Commission (EU Commission 2017b), the fund is designed to provide assistance mainly to stabilize the financial sector and to protect the fiscal sector against spillovers. From the very beginning, the fund was designed to provide conditional assistance; hence, governments have to negotiate a fiscal adjustment programme with the Commission (letter of intent). Only in the two final paragraphs out of more than 70 paragraphs, the Commission's proposal, vaguely and for the distant future, envisages 'new financial instruments', which may be unconditionally and automatically mobilized. In view of the efficiency criterion, the EMF would be an 
improper mix of stabilizing and disciplinary functions, similar to a fire department that takes action only after the owner of a burning house has agreed with the urban administration about a programme for protection against the outbreak of a fire, with the neighbours trembling with fear.

\section{Concluding remarks}

European institutions have been unable to design timely and adequate policy responses to the EA crisis. The institutional setup of the monetary union is grounded in a one-sided manner in the responsibility of each country for a sound fiscal policy stance under all circumstances. The wrong concept of fiscal discipline in turbulent times strengthened shocks, allowed them to proliferate across the area, prolonging the crisis. In particular, there is no fiscal risk-sharing capacity that helps countries protect against shocks that overstrain their resources or result from the spill-over effects from other countries. There is great fear that such a capacity would constitute a super-state and create an unsound fiscal policy in member states that is more attractive in economically calm periods. As an overlay over the existing framework, its establishment does not need a change of the EU Treaties; it can be implemented by Council directives and regulations and thus would complement the institutional setup according to the distinct features of the monetary union. The risk-sharing instrument should be strictly separated from the disciplinary function of the fiscal rules in the monetary union, which will further apply to the member countries, which would make these rules more reliable. A stabilization fund dedicated to investment seems to be the best solution in terms of constitutional sovereignty, institutional efficiency and economic effectiveness.

\section{References}

Acemoglu, D., Ozdagla, A., and Tahbaz-Salehi, A. 2013. Systemic Risk and Stability in Financial Networks. MIT Working Paper 1303.

Allard, C., P.K. Brooks, J.C. Bluedorn, F. Bornhorst, K. Christopherson, F. Ohnsorge, T. Poghosyan, and an IMF Staff Team IMF (2013), "Toward a Fiscal Union for the Euro Area", IMF Discussion Note September

Allen, F. und Gale, D. 2000. Financial contagion, Journal of Political Economy, 108 (1), 1-33.

Asdrubali, P., Bent E. Sørensen, B. E. and Yosha, O. 1996. Channels of Interstate Risk Sharing: United States 1963-1990. The Quarterly Journal of Economics vol. 111, Issue 4, 10811110. 
Baldwin, R., T. Beck, A. Bénassy-Quéré, O. Blanchard, G. Corsetti, P. de Gruwe, W. den Haan, F. Giavazzi, D. Gros, S. Kalemli-Ozcan, S. Micossi, E. Papaioannou, P. Pesenti, C. Pissarides, G. Tabellini and B. Weder di Mauro (2015), "Rebooting the Eurozone. Step 1 - agrreing a crisis narrative. Online: http://citeseerx.ist.psu.edu/viewdoc/summary?doi=10.1.1.702.3923

Battiston, S., Delli Gatti, D., Gallegati, M., Greenwald, B. C., and Stiglitz, J. E. 2012. Liaisons dangereuses: Increasing connectivity, risk sharing, and systemic risk, in Journal of Economic Dynamics and Control, vol. 36, no. 8, 1121-1141.

Begg, I. (2017), "Fiscal Rules and the Scope for Risk Sharing”, Intereconomics 2017/3, 131-137.

Brühl, V., Gründl, H., Hackethal, A., Kotz, H.-H., Krahnen, J. P. and Tröger, T. 2015. Comments on the EU Commission's capital markets union project. Research Center SAFE, White Paper Series No. 27, Universität Frankfurt a. M.

Carnot, N. (2017), "European Fiscal Governance and Cyclical Stabilisation: Searching for a Lasting Arrangement", Intereconomics 2017/3, 148-154.

Cimadomo, J., Fortuna O., and Giuliodoro, M. 2017. Private and Public Risk Sharing in the Euro Area.Tinbergen Institute Discussion Papers 2017-064/VI.

Demary, M., Diermeier, M., and Haas, H. 2015. A capital markets union for Europe: The relevance of banks and markets. Institut der Deutschen Wirtschaft, IW policy paper, no. $18 / 2015$.

Dullien, S. (2008), „Eine Arbeitslosenversicherung für die Eurozone : ein Vorschlag zur Stabilisierung divergierender Wirtschaftsentwicklungen in der Europäischen Währungsunion“. Stiftung Wissenschaft und Politik -SWP- Deutsches Institut für Internationale Politik und Sicherheit Berlin, SWP-Studie S 1.

EU Commission 2012. The Four Presidents' Report: Towards a genuine economic and monetary union. Brussels 5 December 2012. https://ec.europa.eu/priorities/sites/betapolitical/files/5-presidents-report_en.pdf.

EU Commission 2015a. The Five Presidents' Report: Completing Europe's Economic and Monetary Union. Brussels 22. June 2015. http://ec.europa.eu/priorities/sites/betapolitical/files/5-presidents-report_de_0.pdf; Opened: 15 October 2015.

EU Commission 2015b. Green Paper Buildung a Capital Markets Union. http://eurlex.europa.eu/legal-content/EN/TXT/?uri=celex\%3A52015DC0063. Opened: 24. Juni 2016.

EU-Commission (2017a), "Reflection Paper on the Deepening of the Economic and Monetary Union”, Brüssel 2017.

EU-Commission (2017b), “ Proposal for a Council Regulation on the establishment of the European Monetary Fund. Online: https://ec.europa.eu/info/sites/info/files/economy.../com_827.pdf

Feld, P. and S. Osterloh (2013), "Is a fiscal capacity really necessary to complete EA?", Freiburg Discussion Papers 13/5.

Ferrari, A, and A. R. Picco (2016), "International Risk Sharing in the EA", European Stability Mechanism Working Paper 17/2016. 
Fuest, C., A. Peichl (2012), "European Union fiscal union: What is it? Does it work? And are there really 'no alternatives'?”, CESifo Forum, vol 13 (1), 3-9, Munich.

Furceri, D. and A. Zdzienicka ( 2013), "The Euro Area Crisis: Need for a Supranational Fiscal Risk Sharing Mechanism?”, IMF Working Paper, WP 13/198.

Goodhart, C. and R. Lastra (2017), "Populism and central bank independence", Discussion Paper Series, DP 12122, Centre for Economic Policy Research, London, UK.

Iara, A. (2015), "Revenue for EMU: A contribution to the debate on Fiscal Union", Working Paper 54-2015, European Commission, Brussels.

Oates, W. E. (1999), “An Essay on Fiscal Federalism”, Journal of Economic Literature, Vol. 37, No. 3, 1120-1149.

OECD (2014), “OECD Economic Surveys. Euro Area”, OECD Publishing; http://dx.doi.org/10.1787/eco_surveys-euz-2014-en,

Poghosyan, T. (2017), "Cross-Country Spillovers of Fiscal Consolidations in the Euro Area", IMF Working Paper 17/140.

Poncela, P., F. Pericoli, A.R. Manca, and M. Nardo (2016), "Risk sharing in Europe", JRC Science for Policy Report, European Commission, Brussels.

Tinbergen, J. (1952), “On the Theory of Economic Policy”, Amsterdam: North Holland, $2^{\text {nd }}$ edition.

Vandenbroucke, F. (2017), "Risk Reduction, Risk Sharing and Moral Hazard: A Vaccination Metaphor", Intereconomics 2017/3, 154-159.

Véron, N. and Wolff, G.B. (2016), "Capital Markets Union: a Vision for the Long Term", Journal of Financial Regulation, no. 2, 130-153.

Wyplosz, C. (2014), “The Eurozone Crisis: A Near-Perfect Case of Mismanagement”, Economia Marche Journal of Applied Economics, XXXIII(1): 1-13. 